\title{
The Role of Fiscal Policy in the St. Louis Equation
}

\author{
R. W. HAFER
}

$\mathrm{T}$ HE "St. Louis equation" relates the growth of nominal income (GNP) to both the growth of money and high-employment government expenditures. In other words, it attempts to explain changes in GNP by changes in monetary and fiscal actions. One consistent result of estimating the St. Louis equation for the U.S. economy is that monetary actions have a strong and lasting impact on the grow th of GNP, while fiscal actions have only a weak and transitory impact; fiscal effects essentially wash out over four or five quarters.

The purpose of this aticle is to reassess the role of fiscal actions within the framework of the St. Louis equation. As a result of updated estimates and tests, strong evidence is presented reaffirming that fiscal actions are inconsequential in deternining GNP growth, once the effects of money growth are taken into account.

\section{M-SAMPLE WSTHATES}

The St. Louis equation is the foundation for the small-scale monetarist model associated with the Federal Reserve Bank of St. Louis. The nature of the equation (as well as the model) is monetarist because GNP growth is determined primarily by the growth of the nominal money stock. Although the equation recognizes and empirically captures the shortrun effects of stimulative fiscal actions, previous re-

\footnotetext{
Altemative specifications of the St. Lous equation provide othes frameworks in which the role of fiscal actions conld be tested. Our purpose, however, is not to test for the impact of fiscal actions across a broad class of mockels, but to focus attention on the widely recognizad St. Lonis specification. An altemative specifcation may be found in Iohn A. Tatom, "Energy Prices and ShortRun Exononic Perfomance," this Retiet (January 1981), pl. $3-17$.
}

search has demonstrated that fiscal actions have no lasting effect on GNP growth in the St. Louis specification. ${ }^{2}$ Not surprisingly, this finding has been the source of a continuing debate. ${ }^{3}$

The St. Louis equation typically is written as

$$
\text { (1) } \dot{Y}(t)=m_{i}+\underset{i=0}{4} m_{i} \dot{M}(t-i)+\underset{i=0}{\stackrel{4}{y}} e_{i} \dot{E}(t-i)+e(t)
$$

where $\mathrm{Y}$ is nominal GNP, M is the money supplyand $E$ is the meastre of fiscat policy. The dots above the

\footnotetext{
see, for example, Leonall C. Andersen and Jerry L. Jordm "Monetary and Fiscal Actions: A Test of Their Relative Importance in Economic Stabilization," this Retew (November 1968), pp. 11-24; Leonall C. Andersen and Keit) M. Carlson, "A Monetarise Model for Economic Stabilization," this Reciew (April 1970 , pp. 725; Keth M. Carlson, "Does the St. Louis Equation Now Believe in Fiscal Policy?" this Reciew (February 1978), pp. 13-19; Keith M. Calson, "Money, Inflation, and Economic Crow th: Sone Updated Reduced Fom Results and Their Implications;" this Reciew (April 1980, pp. 13-19; and Keith M. Carlson and Sott E. Hein, "Monetary Aggregates as Monetary Indicaton", this Rectew (November 1980), pp. 12-21.

"Earlier wotks inch he Richard G. Davis. "How Much Does Monez Matter? A Look at Sone Recent Eqidence," Fed ral Reserve Bunk of New York Monthly Retiew (June 1969), pp. 119-31; E. Gerald Corrigan, "The Measurement and Importance of Fiscal Policy Changes," Federal Reserve Bank of New York Monthly Review: Gune 1970\%, pla. 133-45; and Edward M. Gramlich, "The Usefulness of Monetary and Fiscal Policy as Diseretionary Stabilization Tools," Joumal of Monety Credit and Banking (May 1971), pp. 506-32. More recent analyses melude Alan S. Blinder and Stephen M. Goldfeld, "New Measures of Fiscal and Monetary Policy, 1958-75,"American Eemunic Rectete (December 1976), pp. 780-96; Benjamin M. Friedman, "Even the St. Louis Model Now Believes in Fiscal Policy," Iownal of Monew. Credit and Banking (May 1977), pp. 365-67; Yash P. Mehra, "An Enpirical Note on Some Monetarist Propositions," Southern Exonomic Jonmal (July 1978), pp. 15467; and $\mathrm{Y}_{\text {ash }} \mathrm{P}$. Mehra and David E. Spencer. "The St. Lonk Equation and Reverse Catusation," Sonthen Economic Joumal Apri 1979), pp. 1,104-20.
} 
variable symbolize rates-of-change, an, $m_{i}$ and $e_{i}$ are parameters to be estimated, and $\epsilon(t)$ is a random error tem. ${ }^{4}$

Through the years, various empirical measures of monetary and fiscal actions have been used to estimate the St. Lous equation. Recent redefinitions of the monetary aggregates rekindled the debate about which aggregate best explains GNP growth. Since recent evidence suggests that $M 1 B$ is the preferred agcregate, it is used in this article. ${ }^{5}$

The consensus choice of the fiscal measure has not yet been resolved. The high-employment federal expenditure measure of fiscal policy is closely associated with the textbook income-expenditure model of the economy. ${ }^{6}$ In that model, government purchases of goods and services plus transfers are considered a direct stimulus to nominal aggregate demand. Consequently, an increase in this measure represents an increase in the government's infuence on nominal demand and, therefore, nominal income. An altemative, the high-employment federal surplus variable, captures the net influence of expenditures and receipts due to the changing pattems in federal government puchases and transfers, and in tax rates. Although other less commonly used measures exist, these two are used in this article to assess the infuence of fiscal actions on the growth of GNP.

Equation 1 was estimated using ordinary least squares for the period $\mathrm{I} / 1960-\mathrm{IV} / 1980$; the regression results are reported in table 1 . Equations $A$ and B show the results obtained using the growth of the high-employment federal expenditures and the change in level of the high-employment federal surplus, respectively. ${ }^{7}$ The results conform with

tThe rate-of-change specification was intoduced by Carlson, who demonstrated that the originat first-difference specification of Andersen and Jordan introduced econometric differlties when estimated into the mid-1970s. See Carlson, "Does the St. Louis Equation Now Believe in Fiscal Policy?"

5 For evidence of the superiority of $M 1 B$, see Carlson and Hein, "Monetary Aggregates as Monetary Indicators;" R. W. Hater, "Selecting a Monetary Indicator: A Test of the New Monetary Aggregates," this Retiew (Febwury 1981), pp. 12-18; and R. W. Hater, "Much Ado About M2," this Reciew (October 1981), pp. $13-18$.

"High-employment" measures are used to reduce the distortion introduced from the impict of the level of economic actity on actual government receipts and expenditures. See heith $M$. Carlson, "Estimates of the High-Employment Budget and Changes in Potential Output," this Reviet (Augest 1977). 1p. $16-22$.

The changes in the high-employment federal surplas variable scaled by income also was ased as an alternative measure of previously reported findings: The summed impact of money growth is not statistically different from unity at the 1 percent level, and the cumulative impact of fiscal actions is not statistically different from zero. The growth of M1B has a significant, sustained influence on the growth of $\mathrm{GNP}$; fiscal actions, measured either as the growth of high-employment federal expenditures or the change in the highemployment federal surplus, do not.

The cumulative impact of the monetary and fiscal variables is statistically comparable with previous results. Indeed, the lag pattern for the money growth variable is essentiatly the same as Carlson reported for a variety of sample periods, ${ }^{8}$ As in previous studies, the impact of money growth on GNP growth is quite rapid: The repercussions of a change in the grow th of money occur within two quarters and fade away by the third and fourth lagged quarters.

The lag patterns for the fiscal variables, in contrast, do not compare ats well to previously reported find ings. When compared with the results for other sample periods, the magnitude of the individual lag coefficients and their significance change dramatically for the fiscal variables. Indeed, it appears that, in addition to having no lasting impact on GNP growth, the fiscal variables exert no significant effect in any quarter. Although econometric difficulties preclude a firm conclusion based on the significance of individual lag estimates, the sensitivity of estimates of the fiscal measures over different sample periods suggests that a GNP-fiscal actions link is dubions. To further examine this issue, three alternative equations were estimated. These equattions isolate the relative explanatory powers of the money and fiscal variables on GNP growth. Estimates from these specifications also are reported in table 1 .

Equation C reports the estimation of equation 1 using only the money growth variable to explain GNP growth. Not surprisingly, the overall explitnatory power of the equation is not diminished substantially by the exclusion of either fiscal policy measure Moreover, the cumulative impact of money growth on GNP growth is not statistically different from unity over the course of one year. This suggests that the money-GNP link in the St. Louis equation is quite robust. The same camnot be said, however, of

fiscal actions. The conclusions reached in the article were not altered by this change.

see Carlson, "Does the St. Louis Equation Now Believe in Fiscal Policy?" and Carlson, "Money, Infation, and Economic Growth." 


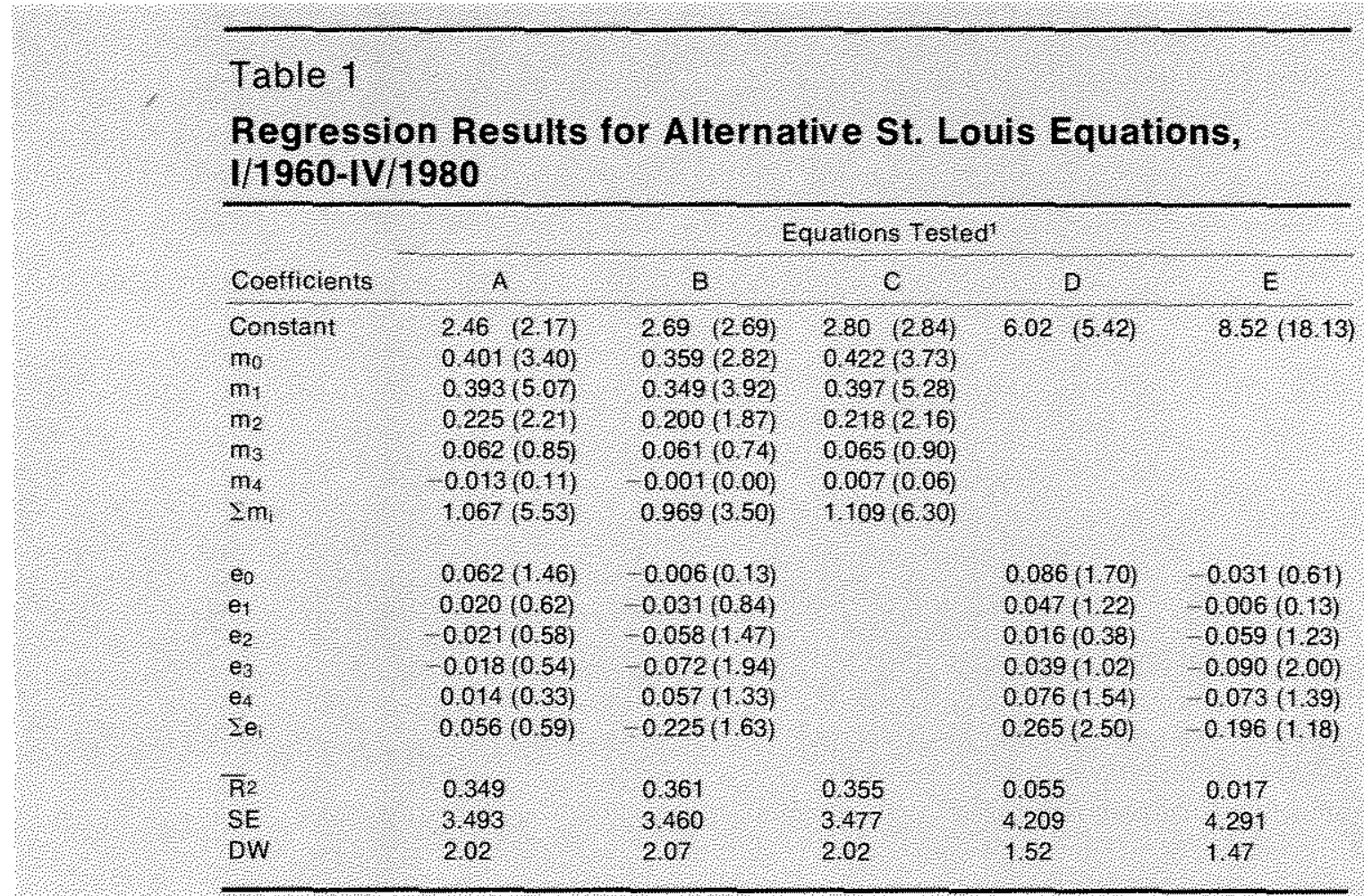

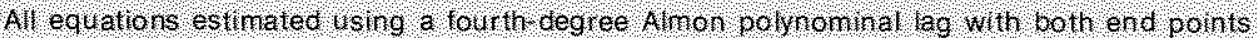
constrained to zero Equatons A and $\mathrm{b}$ use hgh env loyment federal expenditures equaturs B and E use high enplovment federal surplus. MB is the noned neasure used throughout. Absolute values of I-statstics appear in parentheses? $\mathrm{B}$ ? is the coeflicient of determination corrected lor degrees of treedom SE Is the regression standard eror and DW is the DurbinWatson statistic

the empirical relationship between the fiscal actions and GNP.

Equations D and E in table 1 report the results of regressing GNP growth on the growth of highemployment expenditures and changes in the level of high-employment surplus, respectively. In equittion D, the estimated coefficients are noticeably different from those in equation A. The first lag coefficient is more than double the estimate from equation $A$, and the second and third lag terms are positive. More important, the camblative impact for the expenditures variable is positive and statistically significant at the 5 percent level. Untortunately, these results are mared by the existence of significant first-order serial correlation among the residuals, evidenced by the low Dubin-Watson (DW) statistic.

The presence of significant serial correlation in equation $D$ provides important information. One potential cause of serial correlation is the omission of an important explanatory variable which is cyclical. The consequence of such an omission is that the error tem will absorb the cyclical pattern of the variable, and the successive error terms will not be andom. It is clear from a comparison of equations A and $D$ that the excluded variable is the growth of M1B: Adding money growth to equation D eliminates frostorder serial onrelation. If one assumes that equation $\mathrm{A}$ is the "correct" specification, the model represented by equation $\mathrm{D}$ (because it is misspecified) yields coefficient estimates that may be seriously biased and significance tests of questionable efficacy. Thus, the evidence provided by equation $D$ does not support the existence of a significant, lasting affect on GNP growth of fiscal actions captured by the growth of high-employment expenditures.

Equation $\mathrm{E}$ in table 1 presents the results of regressing GNP growth on changes in the highemployment federal sumplus. In line with a priori reasoning, the results suggest that an increase in the size of the high-employment surplas retads GNP growth. Although the summed impact of the surplus variable is of the appropriate sign, it is not statis- 
tically different from zero. This variable does not exert a significant, lasting effect on GNP growth, a finding consistent with equation $B$. The presence of serial correlation, however, again suggests the possibility of a misspecification. This is evidenced by comparing equations $D$ and $B$ : The addition of the money growth variables removes the serial correlation problem. This result indicates that equation $\mathrm{E}$, like equation $D$, is misspecified without the money variable. 9

Any uncertainty about the relative impact of monetary and fiscal actions on GNP growth can be dispelled further by a comparison of equations $A, B$ and $C$ in table 1 . This comparison allows us to address the question "Given the influence of monetary actions on GNP growth, does the information contained in the fiscal variables significantly improve upon money's explanatory power?"

To answer this question, one need only examine the reported t-statistic for the relevant summed variables. For example, equations $A$ and $B$ indicate that adding the fiscal variables to the GNP money regression does not significantly improve the explanatory power: The t-statistics for the respective Ees are not greater than normally acceptable critical values. These results indicate that, once the influence of money growth is accounted for, the atdition of the fiscal varimbles does not statistically improve the explanation of GNP growth. These results further point to the statistical dominance of money growth over either fiscal measure in explaining changes in GNP growth.

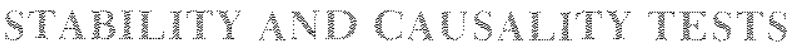

The results of two additional statistical tests are reported in this section. The first test examines the stability properties of the alternative specifications reported in table 1 . The second test provides some evidence about the causal ordering of the monetary and fiscal variables with respect to GNP growth.

To test the temporal stability of the equations presented in table 1 , the $\mathrm{I} / 1960-\mathrm{T} / 1980$ sample period was split at $\mathrm{II} / 1970$ (the mid-point of the sample) and the Chow test was applied. The test

\footnotetext{
9he reader may note that equation $C$, the specification employing only he money growth variabe, is not beset by the probems of senal comelation. This, along with the textual evidence, stongly suggests that the misspecification problems afect only the regessions of GNP growth on fiscal variables.
}

results are reported in table $2 .{ }^{10}$

The Chow test results indicate that the stability hypothesis is rejected only for the regressions of GNP growth on the two fiscal variables, that is, equations $D$ and $F_{\text {: }}$ The calculated F-statistics exced the relevant 5 percent critical value. The calculated F-statistics for the equations that include money grow th or use money growth alone to explitin GNP growth indicate that they provide structurally stable parameter estimates across the I/1960-IV/1980 period. These findings imply that the relationship between GNP growth and money growth has remained relatively stable across the 20 -year sample period. On the other hand, they suggest that the effects of fiscal actions on GNP growth are uncertain and may be quite different across economic environments.

The second test examines the statistical causal ordering between the monetary and fiscal variables and GNP growth. This test procedure, developed by Granger, involves estimating a set of equations for each pair-wise test. ${ }^{11}$ To test for Granger causality, it is assumed that the information relevant to the prediction of the respective variables is contained solely in the data series $Y$ and $X$ (e.g., GNP and money or fiscal variables). The test procedure consists of estimating the equations

$$
\text { (2) } \mathrm{X}(\mathrm{t})=\underset{i=1}{\mathrm{n}}\left\{\mathrm{x}_{i} \mathrm{X}(\mathrm{t}-\mathrm{i})+\underset{j=1}{n} \beta_{3} \mathrm{Y}(\mathrm{t}-\mathrm{j})+\epsilon(\mathrm{t})\right.
$$

and

$$
\text { (3) } \mathrm{X}(\mathrm{t})=\underset{i=1}{\stackrel{m}{2}} \lambda_{1} \mathrm{X}(\mathrm{t}-\mathrm{i})+\underset{j=1}{\stackrel{m}{\geq}} \delta_{j} \mathrm{Y}(\mathrm{t}-\mathrm{j})+\eta(\mathrm{t})
$$

It is assumed that $\epsilon(t)$ and $\eta(t)$ are ancorrelated error series. Unidirectional causation from $\mathrm{X}$ to $\mathrm{Y}$ is

\footnotetext{
10The mid-point was chosen to maximize the power of the test. On this point see foln U. Farley, Melvin Hinich and Timothy $W$. MeGuire, "Sone Comparisons of Tests for a Shitt in the Slopes of a Multivariate Linear Time Series Model," Joumal of Econometrics (August 1975), pp. 297-318. The Chow test may be inappropriate given the existence of serialy currelated erors, as evidenced in equations $D$ and $E$. Fven so, the stability test results in table 2 are based on the ondinary least squares estimation found in table 1 as a matter of consistency. Using GI S estimates of equations $D$ and $E$ in table 1 indicates that the stability hypothesis still is rejected at the 5 percent level: The F-statistics are 3.02 and 3.44 for the CLS estimates of equations $\mathrm{D}$ and $\mathrm{F}$, respectively.

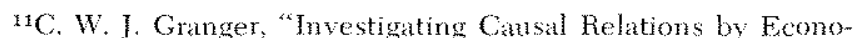
metrie Modes and Cross-Spectral Methods," Econometriea Uuly 1969), pp. 424-38. For a usefel comparison of farious causal tests, see Fdgar L. Feige and Donglas K. Pearce. "The Casmal Causal Relationships Between Money and Incone: Some Caveats for Time Series Analysis," Review of Economics and Sfutistics (November 1979), 1p. 521-33.
} 


\section{Table 2}

\section{Stability Test Results for GNP Equations, 11/1970 Break Point}

\begin{tabular}{|c|c|c|}
\hline Equaton & Palculated $-s$ aristos & Hejeq Shablity \\
\hline 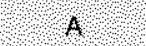 & ?ै? 1,60 & 10 \\
\hline 8 & 162 & 10 \\
\hline 8 & ?tro & No \\
\hline 6 & 288 & Yes \\
\hline 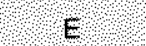 & 362 & Yes \\
\hline
\end{tabular}

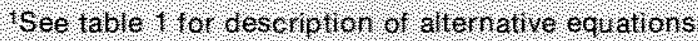

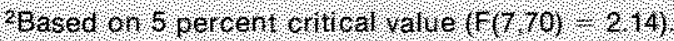

implied if the estimated coefficients on the lagged X variable in equation 2 are statistically different from zero as a group and the set of estimated coefficients on the lagged $Y$ variable in equation 3 is not statistically different from zero. Conversely, unidirectional causation from $\mathrm{Y}$ to $\mathrm{X}$ exists if the set of lagged $\mathrm{X}$ coefficients in equation 2 is not statistically different from zero and the set of lagged $Y s$ in equation 3 is statistically non-zero as a group. Feedback is suggested when the sets of $X$ and $Y$ coefficients are statistically significant from zero in both equations 2 and 3 . Independence occus when the sets of $X$ and $Y$ coefficients are not significant in equations 2 and 3 .

The Gringer test results, based on the I/1960IV/1980 sample, are reported in table $3 .{ }^{12}$ The first pair-wise test is done with money growth and GNP growth $(\dot{\mathrm{M}}, \dot{Y})$. The calculated $\dot{F}$-statistics suggest that there is unidirectional causation from money to GNP. ${ }^{13}$ In the second bivariate test, with the growth of high-employment government expenditures (HEGE), neither $F$-value surpasses the 5 percent critical value. These results suggest that the growth of high-employment expenditures and GNP growth are independent. The last test, which uses the change in the high-employment government

12The estmated equations consist of four tatgyed dependent variables and four lagged "cansal" variables. Because the Granger test requires the data to exbibit stationary characteristics, a tinear time trend and seasonal dammies were entered into the estimated regressions. Moreover, the full-period result: are based on the finding of no structumal break in the extimated test equations. For a futher disenssion and application of the Granger test, see Hafer, "Selecting a Monetary Indicator."

13This finding is stuported by previons empirical research. See Christopher A. Smos, "Money, Income, and Causality," Americam Ecomomic Retiew (September 1972) po. 540-52; Melumand Spencer, "The St, Lonis Equation and Reverse Causation," and Hater, "Selecting a Monetary Indicator." Contury findings are presented in Feige and Pearce, "Casual Camsal Relatonships."

\section{Table 3}

\section{Granger Test Results}

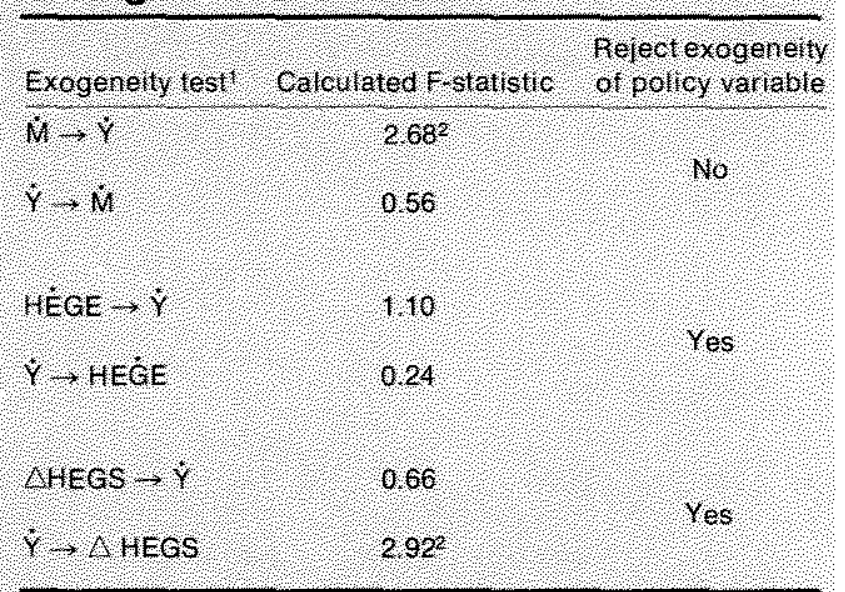

The arrow ndicates hypothesized diection of causally.

signiticant at 5 percent critical value $(\mathrm{f}, 4.71)$ ? 250

surplus variable ( $\triangle \mathrm{HEGS}$ ), indicates that unidirectional causation from GNP growth to changes in the surplus measure cannot be rejected.

To summarize, the statistical evidence suggests that money growth causes GNP growth. The findings presented here provide no empirical support for the "reverse causation" argument. The evidence about the relationship between fiscal measures and GNP growth, however, suggests that GNP causes fiscal actions. This is true specifically for the surplus measure; the outcome for the expenditures variable indicates no causal relationship in either direction (independence). These findings indicate that there is no reliable relationship between $\mathrm{CNP}$ growth and the fiscal measures used in this article. The preceding Chow test results support this conclusion by showing that only the relationship between money and GNP is statistically stable across the entire sample period.

\section{POST-GAMPLE FSTMMTLS}

The final piece of evidence ased to assess the relationship between GNP growth and monetary/ fiscal actions is a comparison of the relative post-sample predictive abilities of selected equations found in table 1 . To this end, each equation initially was estimated from $/ / 1960$ through IV/ 1970. Four-quarter-ahead estimates of GNP growth were then generated using actual values of the money and fiscal measures over this period. The 


\section{Table 4}

Post-Sample Prediction Errors of GNP Growth'

\begin{tabular}{|c|c|c|c|}
\hline \multirow{2}{*}{$\begin{array}{l}\text { Sample period } \\
\text { from } 1 / 960 \text { to } \\
\text { fourth quarter }\end{array}$} & \multicolumn{3}{|c|}{ Equation } \\
\hline & Money onty & $\begin{array}{l}\text { Money growh and high } \\
\text { employment expenditures }\end{array}$ & $\begin{array}{l}\text { Money growthand high- } \\
\text { employment supplus }\end{array}$ \\
\hline 1970 & $0.22 \%$ & $0.20 \%$ & $-0,31 \%$ \\
\hline 1971 & 2.06 & 158 & 198 \\
\hline 1972 & 1.35 & 207 & 110 \\
\hline 1973 & -1.18 & -183 & 0.18 \\
\hline 1974 & 228 & 201 & 069 \\
\hline 1975 & 041 & 065 & 170 \\
\hline 1976 & 123 & 114 & 136 \\
\hline 1977 & 258 & 280 & 294 \\
\hline 1978 & 183 & 194 & 0.48 \\
\hline 1979 & -011 & 0.60 & 1,40 \\
\hline Average Eror & $070 \%$ & $0,61 \%$ & $073 \%$ \\
\hline
\end{tabular}

estimation period was then extended to include the four quarters of 1971, and four-quarter-ahead forecasts for 1972 were constructed. This procedure was continued each year through 1980 . The average errors in predicting GNP growth are presented in table 4. Since the purpose of these comparisons is to determine if the alternative fiscal policy measures add anything to the estimates of GNP growth once money growth is known, results for three equations are presented: money only, money and highemployment expenditures, and money and highemployment surplus.

The results in table 4 indicate that, on average, money alone (equation $\mathrm{C}$ ) results in GNP growth prediction errors that are less than 1 percentage point. The addition of the expenditures measure of fiscal policy (equation A) leads to only a marginal reduction in the average error, while the addition of the surplus measure (equation B) leads to a marginal increase in the average forecast error. Although these changes may appear rather substantial, tests reveal that the average errors for the altemative specifications are not statistically different. In fact, the calculated $t$-statistics comparing the ave anges are all less than unity. ${ }^{14}$ Based on the equations' relative predictive abilities, therefore, one would do just as

\footnotetext{
1. For instance, the t-statistic conpuring the average erom term from the "money only" regression to that using money and the expenditures viriable is 0.14 . The statistic comparing money only and the regression using the surplus measure is -0.50 .
}

well, on average, to use only money growth to predict future GNP growth as using money growth and either of the two fiscal policy measures examined in this article.

\section{CONCLUSION}

This paper has re-examined the role of fiscal policy in the context of the St. Louis equation. The results are broadly consistent with previous findings. Specifically, fiscal actions exert neither a significant nor lasting impact on the growth of GNP.

Alugmenting previous work, however, the results here provide futher evidence against the reliance on fiscal policy measures to explain movements in GNP. Three conclusions can be drawn from these test results: The fiscal policy measures 1) do not significantly increase the explanatory power or forecasting ability of an equation that already incorporates money growth; 2) do not exhibit stable statistical relationships whth GNP growth; and 3) are not exogenous with respect to GNP growth. The evidence suggests that fiscal actions are ineffective for stabilization purposes. Moreover, the results add increasing stature to the use of monetary policy as a tool in stabilizing fuctuations in economic activity.

Comparing the mean torecasts generated by the two fiscal equattions yielded at-statistic of -0.19 